\title{
NATURAL CALAMITIES IN AGRICULTURE AND THEIR INSURABILITY IN ROMANIA
}

\author{
Assistant PhD Student Sorin Ciprian Teiuşan, \\ Associate Professor Ph.D. Adela Socol, \\ Associate Professor Ph.D. Iulia Iuga, \\ “1 Decembrie 1918” University of Alba Iulia
}

\begin{abstract}
The paper explains how are interpreting the natural calamities in the acceptation of Romanian authorities. It describes the agricultural policies in Romania, concerning the agricultural insurance. It emphasizes that the agricultural producers that insure their agricultural culture, animals, fowls, bees and fish at the granted insurance companies, in the natural calamities situation, are sustained by State. In the end, the paper describes the typology of agricultural insurance active in Romania, the companies which are implied in this field of activity and their importance in the agriculture insurance market.
\end{abstract}

The research of the agricultural insurance is indispensable connected with the study of agricultural risks. The risks directly affecting the income and welfare of agricultural producers are many: production, marketing, financial, regulatory, ecological, strategic risks etc. To manage these risks, farmers must choose their production or marketing methods carefully and try to diversify their sources of income.

In most cases, specialized studies ${ }^{1}$ describe the various types of risks and crises in agriculture and the instruments available to deal with them. Risk implies a situation, which could have a variety of outcomes, for each of which the probability can be estimated. Although risktaking is often a pre-requisite to making progress, a negative outcome could have serious economic consequences for a business.

An important risk in agriculture is the production risk, concerning agricultural output or yields. The production risk is often related to adverse weather conditions, plant or animal diseases or pests. Livestock production is generally considered to be less affected by output variability than crop production, since in many respects the production environment is easier to control. Sanitary crises, however, may result in severe income losses.

Depending on risk management possibilities, we can divide agricultural risks into ${ }^{2}$ :

- systemic (fundamental) risk, which affects an entire area or group of people wholly, including war, earthquake, extensive pollution, etc. In this case, the effects are extremely complex and private insurance often fails to cover them;

- syncretic (specific) risk, affecting surfaces, sectors or people in a heterogeneous way.

The higher the systemic risk component, the lesser the probability that a farmer could efficiently manage risk on his own.

The types and extent of agricultural risks vary widely among the European Union member states, as do the tools developed to cope with these exposures. Common Agricultural Policy CAP guidelines have given each European Union member state great freedom in responding to its unique

\footnotetext{
1 The studies are: European Commission Agriculture Directorate-General, Working Document "Risk Management Tools for EU Agriculture with a special focus on insurance", January 2001 and Commission of the European Communities, "Commission Staff Working Document on risk and crisis management in agriculture", Brussels, SEC (320), 2005

${ }^{2}$ D.C.Dănulețiu, Asigurări comerciale, Risoprint Publishing House, Cluj-Napoca, 2007, pp. 213-214.
} 
risks, with the result being a proliferation of products that differ considerably from state to state in terms of structure, coverage, complexity, and degree of state aid.

According to the European authorities' opinion, agricultural insurance is a useful tool for covering certain specific risks, but it cannot replace the public authorities when it comes to managing exceptional risks. The insurance is considered ${ }^{3}$ like an instrument available to European Union agriculture in risk and crisis management. Insurance covering limited climatic risks, such as hail, is available to most EU farmers. Two main problems may hold back the development of commercial insurance products covering a wider range of yield, price or revenue risks. First, production and, in particular, price risk can be systemic, i.e. many farmers are affected at the same time. Second, asymmetric information limits insurance companies in calculating the probability of losses and may lead to adverse selection (only farmers at high risk buy insurance) and moral hazard (clients of insurance reduce their efforts to avoid damage). As a result, the availability of insurance to the agricultural sector is limited, which is the principle argument used by some public authorities to justify intervention.

For the insurance industry, reinsurance is a further obstacle to setting up agricultural insurance products, since the capacity of the worldwide reinsurance market is limited.

Previously 2002 year in Romania it cannot be identify in legislation plan not even a specific settlement of diminution the risk which taxed the agricultural system. Through law nr.381/2002 regarding the grant of compensation in case of natural disaster in agriculture, the Romanian authorities became in support of agriculture producers. They are considered agricultural producers, physical or juridical persons which have in administration or exploration agricultural fields, animals, birds, bee houses and fishes.

Naturals disasters are the quantitative and qualitative losses of crops, the death rate and/or the necessity of slaughter of animals, produced through destructive manifestation of natural phenomenon and diseases, on specific spreading areas. Naturals phenomenon's that generates natural disasters are:

a) excessive complex drought, lasting in time and which affects the unirrigated fields, is the meteorological phenomenon that associates atmospheric drought with pedological drought determining perturbations in vegetal situations of plants which lead to qualitative and quantitative diminutions of crops and even the partial or total compromise of those;

b) the floods from the overflowing rivers or other running waters, determined by natural causes and which produces damages to the agricultural crops and animals;

c) the break of dam produced by natural causes and through hid destructive effect produces damages to the agricultural crops and animals;

d) teeming and long rains which determine the hidric stress, produced by the excess of humidity from soil, with different degrees of intensity, producing stagnation and disordered of the increases processes and plants development;

e) excessive low temperatures, under the biological limit of plants resistance, which processes the slow down process of plants and the partial or total destruction of agricultural crops;

f) the dense stratum of snow that produces damages in the vegetal and animal aria;

g) the unexpectedly melting of snow, which produces floods, overflows of rivers, stagnation and produces damages of agricultural crops and animals;

h) hurricane - strong wind of $80 \mathrm{~km} / \mathrm{hour}$;

i) disasters and other naturals disasters which are being produced on extensive arias and bring significant damages to the agricultural producers;

j) diseases of cultivated plants which in favorable conditions generates natural disasters: to the grain crops - Erysiphe spp; Septoria spp; Puccinia spp; Fusarium spp; sunflower crops -

\footnotetext{
3 European Commission Agriculture Directorate-General, Working Document "Risk Management Tools for EU Agriculture with a special focus on insurance", January, 2001
} 
Sclerotinia sclerotiorum; Phomopsis-Diaporthe helianthi; grape vine - Plasmopara viticola; fruit tree - Erwinia amylovora;

$\mathrm{k})$ the animal diseases that generates natural diseases:

- diseases from A list of the International Office of Epizooty foot and mouth diseases, stomatitis verzicolor, verzicolor disease of pig, cattle plague, ruminant little plague, cattle phuropneumonia contagious, viral dermatitis nodule, Riff vale fever, Bluetongue, variola ovine and caprinae, African plague of horse, African plague of porcine, classical porcine plague, aviary plague and pseudo plague aviary;

- diseases from B list of the International Office of Epizooty like encephalopathy sponge

cattle

Agricultural producers, physical and juridical persons can benefit from compensation for natural diseases produced by the natural phenomenon's and the diseases presented in this study, only for agricultural crops, animals, birds, bee houses and fishes which were insured by the insurance companies and insurance and reinsurance for natural phenomenon and diseases. In this way, the Romanian authorities achieved a condition between compensation of agricultural producers and the insurance policy of agricultural crops.

The maxim dead line of insurance contract of crops is 15 December for sown crops in autumn and 31 May for the sown crops in spring and for plantation. Not only insurance policy of agricultural type leads to the compensation of agricultural producers. Every year, Romanian authorities selects certain insurance companies, relying on the approval of insurance societies and the insurance reinsurance is made annual by the Ministry of Agriculture and Rural Development and the Committee of insurance Supervision.

The compensation are granted to the agricultural producers for the crops and plantations affected by the natural disasters, only for damages that overrun $30 \%$ of the production, the maxim level of compensation is $70 \%$ from the expenses made by the time the phenomenon occurred.

The level of compensation granted on unit area for crops and plantations affected by the natural disasters, that had registered damages over $30 \%$ of the production is settle by applying percentage of damages to the value of the expenses made by the time of the phenomenon, but not more than $70 \%$ from those values.

On areas affected by natural disasters, the value of compensation given to agricultural producers from the state budget decreases with the sum receives from the insurance societies and insurance-reinsurance.

The establish of the damages percentage for the crops is made through references of the expressed production in physical units, damaged by natural disasters, to the production expressed in physical units, registered in the insurance policy closed with insurance and insurance- reinsurance societies. For the establish of the level of expenses made at the crops and plantations which were affected, the agricultural producer must prove the implementation of those works.

There is a finding procedure of damages, in present of agricultural producer affected and a committee of specialists. It is also used a tip documentation for registering the damages of the crops and animals.

In the second part of the $19^{\text {th }}$ century, just a few insurers in Romanian Principality were dealing with agricultural insurance, but this activity was not a principal one. A certain similarity can be remarked in the period after 1989. In the ' 90 just two insurers, namely AGRAS and ASIROM, were dealing with agricultural insurances ${ }^{4}$.

In the present, corresponding the dates given by National Union of Insurance and Reinsurance Societies in Romania, for 30 June 2006 the statistics shown the next situation for fire insurance and natural disasters:

\footnotetext{
${ }^{4}$ Dănulețiu D. C., Agriculture insurances by the main insurances societies from Romania, Procont Review, nr. 2, Alba Iulia, 2004, pag. 69.
} 
In Romania, at 31.12.2006 there were authorized to spread insurance activities, in accordance with legal valid previsions, 41 insurance societies. From those, during the year 2006, carried on insurance activities 40 societies, from which: 21 societies carried on only general insurance activities, 8 societies carried on only life insurance and 11 societies carried on only composite activities, practicing both categories of insurance.

There are 18 categories of general insurances: I. Comprehensive insurance; II. Health insurance; III. Land means of transportation insurance; IV. Railway means of transportation insurance; V. Aerial means of transportation insurance; VI. Maritime, lakeside, fluvial, means of transportation insurance; VII. Goods of transit insurance; VIII. Fire and natural disasters insurance; IX. Other goods insurance; X. Civic responsibility for auto vehicles insurance; XI. Civic responsibility for aerial means of transportation insurance; XII. Civic responsibility for Maritime, lakeside, fluvial, means of transportation insurance; XIII. General civic responsibility insurance; XIV. Credits insurance; XV. Guarantee insurance; XVI. Financial looses insurance; XVII. Juridical protection insurance.

\section{The structure on categories of gross bonuses subscribed from the general insurances in 2006.}

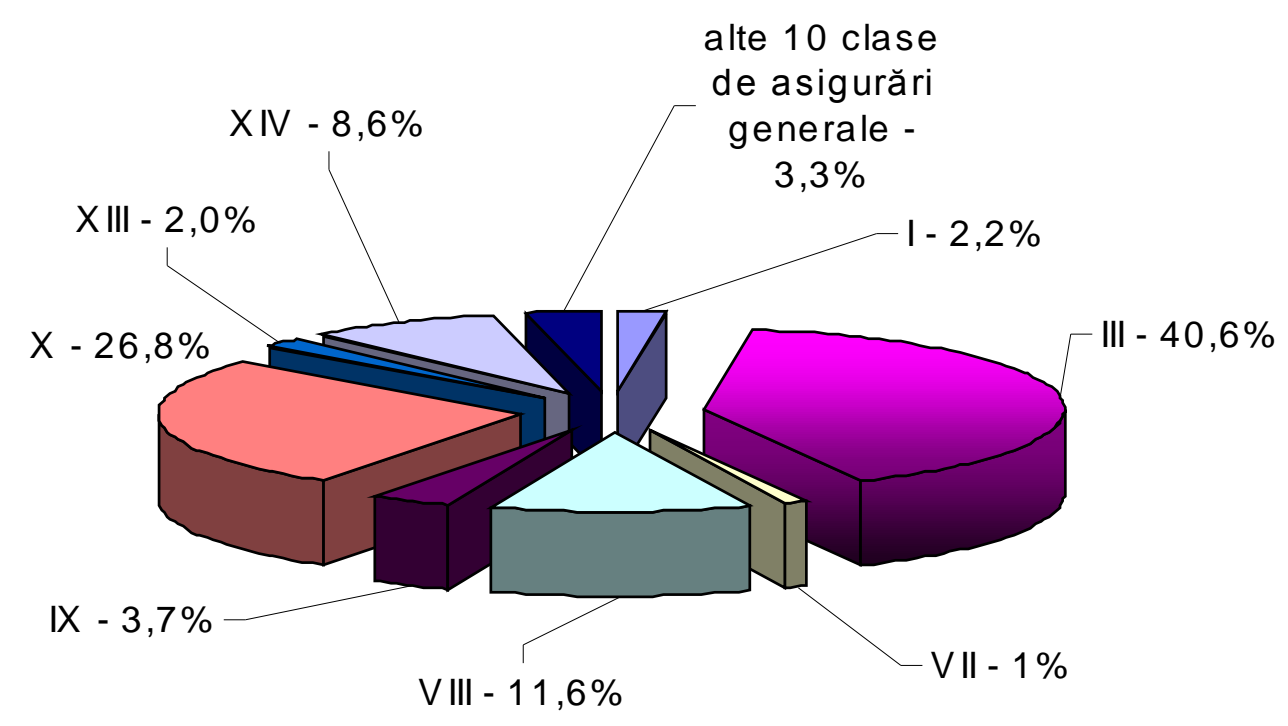

From the analyzed structure on first gross bonuses subscribed from general insurance, results that in 2006, 4 categories of insurance owns over $87 \%$ from grosses namely:

A) III category - land means of transportation insurance, other than railway- with a value of 1.864.567.015. lei (551.369.730 euro), representing $40.6 \%$ from the total gross bonuses, subscribed for general insurance, registered real increase compared to 2005 with $32.49 \%$

B) $\mathbf{X}$ category - civic responsibility for auto vehicles insurance- with a value of 1.231.265.386 lei (the equivalent of 364.096 .574 euro), representing $26.8 \%$ from gross bonuses subscribed for general insurance, in real increasing compared to 2005 with $21.64 \%$

C) VIII category - fire and natural disasters insurance for which were subscribed gross bonuses in amount of 534.070.875 lei (the equivalent of 157.929 .703 euro), representing $11.6 \%$ from the total afferent of general insurance, in increasing compared to 2005 with $8.23 \%$ in real terms. Over $80 \%$ from the gross bonuses afferent to this category had been subscribed to the next societies, the accumulated share own by this, in the mentioned category is $81.2 \%$ :

1. ALLIANZ TIRIAC, with 131.340 .137 lei (38.838.494 euro), representing $24.6 \%$ from the total volume of subscribes for this category, in real increasing with $0.03 \%$ compared to 2005 ; 
2. ASIBAN with 36.266 .575 lei (10.724.362 euro), representing $6.8 \%$ from the total bonuses subscribed at this category, in real annual increasing with $42.43 \%$;

3. ASIROM with55.298.057 lei (16.352.148 euro), representing $10.4 \%$ from the total category in real increasing with $14.09 \%$ compared to 2005 ;

4. ASITO KAPITAL with20.464.766 lei (6.051.621 euro), meaning 3.8\% from the total bonuses subscribed to this category in increasing with $6.55 \%$ in real terms compared to 2005 ;

5. BCR ASIGURARI with a volume of subscribed bonuses at this category of 38.095 .378 lei (11.265.156 euro), representing a share of $7.1 \%$ in real increasing with $18.01 \%$;

6. GENERALI ASIGURARI with 34.669.490 lei (10.252.089 euro), representing $6.5 \%$ from the total category, in real increasing with $16.33 \%$;

7. OMNIASIG, with 78.888 .809 lei (23.328.151 euro), representing $14.8 \%$ from the total volume, in real increasing with $31.22 \%$ compared to 2005 ;

8. UNITA with 38.549 .395 lei (11.399.413 euro), representing $7.2 \%$ from the total category, in real increasing with $70.95 \%$.

D) XIV category - credits insurance with a value of subscribed gross bonuses of 395.897.908 lei (117.070.667 euro), representing 8.6\% from the total gross bonuses subscribed at general insurance, in real increasing with $44.11 \%$ compared to 2005 .

In the field of general insurances, the given bonuses in reinsurance had been in amounting to 1.470.967.468 lei (434.978.700 euro), representing 32.0\% from the total bonuses subscribed at this category being with $51.18 \%$ bigger in real terms, than the presented volume of last year.

Analyze of structure a categories of general insurances of gross bonuses given up in reinsurance shown that significant ponder had been registered at three categories of insurance namely:

- III category - Land means of transportation insurance others than railway with a volume of bonuses given up of 499.807 .097 lei (147.797.586 euro), representing $34 \%$ from the total bonuses given up for general insurance

- VIII category - Fire and natural disasters insurance with a volume of given up bonuses in reinsurance of 355.596 .086 lei (105.153.0055 euro), representing $24.2 \%$ from the total bonuses given for general insurance, in real increasing with $25.43 \%$ compared to 2005

- XIV category - Credits insurance with a volume of given bonuses of 274.436.358 lei (81.153.372 euro), representing $18.7 \%$ from the total, with $59.75 \%$ bigger than in 2005 in real terms. Regarding the paid allowance on general insurance categories in 2006 (lei) for VIII category were 75.073.618 lei.

Extremely useful in the development of a performing agriculture, closing insurances against natural disasters in agriculture is dealing from the insurance point of view with a series of problems, principals aspects being the lack of money resource of potential insurants, as well as small lands that do not permit a correct evaluation of agricultural production that can be obtain. 
Indicators about fire and natural disasters insurance

\begin{tabular}{|c|c|c|c|c|c|c|c|c|c|c|c|}
\hline No. & Society & $\begin{array}{c}\text { Bonuses } \\
\text { gross } \\
\text { subscribed }\end{array}$ & $\begin{array}{l}\text { Bonuses } \\
\text { Gross } \\
\text { received }\end{array}$ & $\begin{array}{c}\text { Net } \\
\text { reserve } \\
\text { from first } \\
\text { to } \\
\text { 1.01.2006 }\end{array}$ & $\begin{array}{c}\text { Net reserve } \\
\text { from first to } \\
\mathbf{3 0 . 0 6 . 2 0 0 6}\end{array}$ & $\begin{array}{l}\text { Giving up } \\
\text { in } \\
\text { reinsurance }\end{array}$ & $\begin{array}{l}\text { Receives in } \\
\text { reinsurance }\end{array}$ & $\begin{array}{c}\text { Gross } \\
\text { damages } \\
\text { paid }\end{array}$ & $\begin{array}{c}\text { Net } \\
\text { damages } \\
\text { paid }\end{array}$ & $\begin{array}{c}\text { Net } \\
\text { reserves } \\
\text { of } \\
\text { damages } \\
\text { at } \\
1.01 .2006\end{array}$ & $\begin{array}{c}\text { Net reserves of } \\
\text { damages at } \\
\text { 30.06.2006 }\end{array}$ \\
\hline 1 & ALLIANZ ȚIRIAC & $73.577,2$ & $69.192,4$ & $34.302,3$ & $25.712,9$ & $77.616,5$ & 0,0 & $12.234,8$ & $-1.247,8$ & $5.503,8$ & $4.242,8$ \\
\hline 2 & ARDAF & $7.982,4$ & $5.762,8$ & $1.480,5$ & $5.943,9$ & $3.340,4$ & 0,0 & 674,5 & 626,2 & 340,1 & $1.475,7$ \\
\hline 3 & ASIBAN & $16.566,0$ & $15.320,0$ & $8.762,0$ & $8.286,0$ & $10.776,0$ & 0,0 & $2.165,0$ & $1.353,0$ & $1.385,0$ & $1.736,0$ \\
\hline 4 & ASIROM & $27.889,5$ & $27.805,7$ & $18.549,5$ & $18.697,9$ & $9.521,7$ & 1,9 & $4.654,2$ & $4.045,5$ & $1.989,2$ & $4.419,4$ \\
\hline 5 & ASITRANS & 508,4 & 399,1 & 74,5 & 152,3 & 67,8 & 0,0 & 15,5 & 13,4 & 4,4 & 3,4 \\
\hline 6 & ASTRA & $6.542,4$ & $5.489,3$ & $2.359,8$ & $3.603,6$ & $1.970,4$ & 0,0 & 979,3 & 979,3 & 687,4 & 777,1 \\
\hline 7 & AVIVA & - & - & - & - & - & - & - & - & - & - \\
\hline 8 & BCR ASIGURARI & $17.213,1$ & $16.297,0$ & $12.763,2$ & $11.060,5$ & $13.126,0$ & 0,0 & 962,2 & 559,6 & $1.036,3$ & $1.931,9$ \\
\hline 9 & BT ASIGURARI & $6.798,1$ & $6.936,0$ & $6.869,1$ & $7.984,9$ & $1.124,9$ & & $1.025,2$ & $1.025,2$ & 919,6 & $1.891,6$ \\
\hline 10 & CARPATICA ASIG & $1.995,5$ & $1.713,3$ & $1.082,5$ & $1.010,3$ & 787,3 & 0,0 & 56,2 & 54,5 & 72,9 & 107,1 \\
\hline 11 & EXIMBANK & - & - & - & - & - & - & - & - & - & - \\
\hline 12 & GARANTA & $3.561,0$ & $3.015,9$ & 906,9 & 993,9 & $2.118,1$ & 0,0 & 126,6 & 46,0 & 118,9 & 148,0 \\
\hline 13 & GENERALI & $17.829,4$ & $17.567,5$ & $3.835,5$ & $4.779,3$ & $12.919,1$ & 678,5 & 780,6 & 350,1 & $1.352,2$ & $1.681,8$ \\
\hline 14 & GRAWE & - & - & - & - & - & - & - & - & - & - \\
\hline 15 & ING & - & - & - & - & - & - & - & - & - & - \\
\hline 16 & INTERAMERICAN & $3.006,7$ & $1.979,1$ & 974,2 & $1.225,5$ & $2.127,0$ & 0,0 & 297,3 & 60,2 & 100,7 & 96,3 \\
\hline 17 & RAI & 378,0 & 332,0 & 124,0 & 104,0 & 318,0 & 0,0 & 35,0 & 3,0 & 5,0 & 10,0 \\
\hline \multicolumn{2}{|r|}{ TOTAL } & $183.847,6$ & 171.810,0 & $92.084,0$ & $89.554,9$ & $135.813,2$ & 680,4 & $24.006,4$ & $7.868,1$ & $13.515,6$ & 18.521,0 \\
\hline
\end{tabular}




\section{Bibliography:}

1. D.A. Constantinescu, "Assurance Treaty", Semne 94 Publishing House, Bucuresti, 1999

2. I. Văcărel, F. Bercea, "Insurances and reinsurances", Expert Publishing House, Bucuresti, editia a II-a, 2000

3. Dănulețiu D., "Agriculture insurances by the main insurances societies from Romania", Procont Review, nr. 2, Alba Iulia, 2004

4. Dănulețiu D.C., "Commercial insurances", Risoprint Publishing House, Cluj-Napoca, 2007.

5. Dismukes Robert, John Bird Jr., Fred Linse, Risk Management Tools in Europe: Agricultural Insurance, Futures and Options, Agriculture and Trade Report No. (WRS04-04), February 2004

6. Ramune Uosyte, Crop insurance in European Union countries, paper presented at the International Conference Challenges for Rural Development and Agri-Food Sector in 2007-2013, Lithuanian Institute of Agrarian Economics, Vilnius, 14-15 December 2005.

7. European Commission Agriculture Directorate-General, Working Document "Risk Management Tools for EU Agriculture with a special focus on insurance", January 2001,

8. The Supervision Insurance Committee Report regarding development activity and insurance market evolution in 2006. 